\title{
Air pollution control and decreasing new particle formation lead to strong climate warming
}

\author{
R. Makkonen ${ }^{1}$, A. Asmi ${ }^{1}$, V.-M. Kerminen ${ }^{1,2}$, M. Boy ${ }^{1}$, A. Arneth $^{3,4}$, P. Hari ${ }^{5}$, and M. Kulmala ${ }^{1}$ \\ ${ }^{1}$ Department of Physics, University of Helsinki, P.O. Box 64, 00014 University of Helsinki, Finland \\ ${ }^{2}$ Finnish Meteorological Institute, P.O. Box 503, 00101 Helsinki, Finland \\ ${ }^{3}$ Department of Physical Geography and Ecosystems Analysis, Lund University, 22362 Lund, Sweden \\ ${ }^{4}$ Institute of Meteorology and Climate Research, Karlsruhe Institute for Technology, Kreuzeckbahnstr. 19, \\ 82467 Garmisch-Partenkirchen, Germany \\ ${ }^{5}$ Department of Forest Science, University of Helsinki, P.O. Box 27, 00014 University of Helsinki, Finland \\ Correspondence to: R. Makkonen (risto.makkonen@helsinki.fi)
}

Received: 26 August 2011 - Published in Atmos. Chem. Phys. Discuss.: 19 September 2011

Revised: 20 January 2012 - Accepted: 26 January 2012 - Published: 8 February 2012

\begin{abstract}
The number concentration of cloud droplets determines several climatically relevant cloud properties. A major cause for the high uncertainty in the indirect aerosol forcing is the availability of cloud condensation nuclei $(\mathrm{CCN})$, which in turn is highly sensitive to atmospheric new particle formation. Here we present the effect of new particle formation on anthropogenic aerosol forcing in present-day (year 2000) and future (year 2100) conditions. The present-day total aerosol forcing is increased from $-1.0 \mathrm{~W} \mathrm{~m}^{-2}$ to $-1.6 \mathrm{~W} \mathrm{~m}^{-2}$ when nucleation is introduced into the model. Nucleation doubles the change in aerosol forcing between years 2000 and 2100 , from $+0.6 \mathrm{~W} \mathrm{~m}^{-2}$ to $+1.4 \mathrm{~W} \mathrm{~m}^{-2}$. Two climate feedbacks are studied, resulting in additional negative forcings of $-0.1 \mathrm{~W} \mathrm{~m}^{-2}(+10 \%$ DMS emissions in year 2100$)$ and $-0.5 \mathrm{~W} \mathrm{~m}^{-2}(+50 \%$ BVOC emissions in year 2100$)$. With the total aerosol forcing diminishing in response to air pollution control measures taking effect, warming from increased greenhouse gas concentrations can potentially increase at a very rapid rate.
\end{abstract}

\section{Introduction}

Atmospheric new particle formation is a frequent phenomenon that enhances aerosol particle number concentrations almost everywhere in the troposphere (Kulmala et al., 2004; Spracklen et al., 2006, 2010; Yu et al., 2010). While the initial nucleation occurs at about $1-2 \mathrm{~nm}$ of particle diameter, nucleated particles are able grow up to cloud condensations nuclei $(\mathrm{CCN})$ sizes if sufficient amounts of condensable vapours are available (Lihavainen et al., 2003; Merikanto et al., 2009; Pierce and Adams, 2009; Yu and Luo, 2009). By this way, atmospheric new particle formation affects cloud droplet number concentrations (CDNC) (e.g., Kerminen et al., 2005; Makkonen et al., 2009; Merikanto et al., 2010). Modifications to cloud droplet concentrations lead to aerosol indirect effects, namely the cloud albedo effect (Twomey, 1974) and cloud lifetime effect (Albrecht, 1989). The potential effect of nucleation on aerosol indirect effects has been shown with global climate models (Wang and Penner, 2009; Kazil et al., 2010).

Sulphuric acid is thought to be the main precursor for atmospheric nucleation (Kulmala et al., 2006; Kerminen et al., 2010; Sipilä et al., 2010), hence the emissions of oceanic dimethyl sulphide (DMS) and both natural and anthropogenic sulphur dioxide are expected to dominate the new particle formation process. Anthropogenic $\mathrm{SO}_{2}$ emissions have increased by three orders of magnitude in the last $250 \mathrm{yr}$, from $0.06 \mathrm{Tg}(\mathrm{S}) \mathrm{yr}^{-1}$ in the year 1750 to $54 \mathrm{Tg}(\mathrm{S}) \mathrm{yr}^{-1}$ in the year 2000 (Dentener et al., 2006). However, the global $\mathrm{SO}_{2}$ emissions might already have peaked in the early $1970 \mathrm{~s}$ (Smith et al, 2011), and the application of flue-gas desulfurization in power plants has decreased emissions in China by $9.2 \%$ between 2006 and 2010 (Lu et al., 2011). Due to the relatively easy suppression of $\mathrm{SO}_{2}$ emissions, the projected future emission pathways show a strong decrease in global emissions. Recently, "Representative Concentration Pathways" (RCPs) (Moss et al., 2010; Lamarque et al., 2011) have been introduced for the scenario development process of IPCC AR5. All RCPs project a significant decrease in 
global anthropogenic $\mathrm{SO}_{2}$ emissions, with annual emissions ranging from $6.5 \mathrm{Tg}(\mathrm{S})$ to $13 \mathrm{Tg}(\mathrm{S})$ in the year 2100. Not only the $\mathrm{SO}_{2}$ emissions are expected to decrease: global emissions of fossil fuel organic and black carbon are predicted to peak before 2030 and then to decline rapidly, such that the levels at 2100 would be close to those at 1850 . However, most RCPs predict a continuous increase of ammonia emissions, at 2100 being 3 to 5 times those at 1850 . Future emissions of biomass burning aerosols behave very differently between the different RCPs in terms of both the sign of the trend and absolute emission levels. The estimated present-day to future changes in oceanic DMS emissions are rather small: $+6.5 \%$ (Ramaswamy et al., 2001) $+2.4 \%$ (Bopp et al., 2004) and $-8.0 \%$ (Stier et al., 2006).

Despite its importance for nucleation, sulphuric acid can explain only a fraction of the subsequent nuclei growth. Oxidation products of biogenic volatile organic compounds (BVOCs) may provide the required growth for aerosols to reach CCN sizes (Jimenez et al., 2009; Paasonen et al., 2010). In addition, certain organic compounds might also play a role in the first steps of nucleation (Metzger et al., 2010). However, the centennial-scale changes in BVOC emissions are highly uncertain, ranging from almost zero to increases by more than $70 \%$, depending on which processes are considered in the underlying emission algorithms and prognostic vegetation models (Lathière et al., 2005; Arneth et al., 2007).

Our aim is to study aerosol-cloud-climate interactions in three emission environments: pre-industrial, present-day and future. We provide a quantification of the impact of aerosol nucleation on particle and cloud droplet number concentrations and anthropogenic aerosol forcing, accounting also for the possible impact of increase in biogenic precursor emissions (BVOCs and oceanic DMS).

\section{Methods}

\subsection{Global aerosol-climate model ECHAM5-HAM}

We use the global climate model ECHAM5-HAM (Stier et al., 2005) to simulate aerosol concentrations, cloud properties and total aerosol forcing with pre-industrial (year 1750), present-day (year 2000) and future (year 2100) emissions. The model is run in a T42 spectral resolution, corresponding to a mean horizontal resolution of $2.8^{\circ}$. In the vertical, 31 levels extend from surface up to $10 \mathrm{hPa}$. ECHAM5-HAM includes the aerosol microphysics model M7 (Vignati et al., 2004), which considers dust, sea salt, black carbon (BC), particulate organic matter $(\mathrm{OC})$ and sulfate. Nitrate aerosols are not included in the model. Aerosol size distribution is described by four soluble (internally mixed) and three insoluble (externally mixed) log-normal modes: nucleation-mode (particle radius $r<5 \mathrm{~nm}$ ), Aitken-mode $(5 \mathrm{~nm}<r<50 \mathrm{~nm}$ ), accumulation-mode $(50 \mathrm{~nm}<r<500 \mathrm{~nm})$ and coarse-mode $(r>500 \mathrm{~nm})$. The mode standard deviations are constant: 2.00 for the coarse modes and 1.59 for other modes. Binary sulphuric acid nucleation (Vehkamäki et al., 2002) is included throughout the atmosphere, and activation-type nucleation (Kulmala et al., 2006) is constrained to the boundary layer. We assume monoterpene oxidation products to form SOA with a $15 \%$ yield, and this organic mass is partitioned to the aerosol phase according to condensation sink of each mode (Makkonen et al., 2009) in the boundary layer during one timestep. No organics are traced in the gas-phase. The modal setup of M7 is not ideal for studies of new particle formation: for example, nucleation mode can not keep track of newly formed particles and at the same time model the growth of aged particles. To improve this, we convert the nucleated particles to $3 \mathrm{~nm}$ size by using a parameterization by Kerminen and Kulmala (2002). Some of the numerical problems in the modal approach could be avoided by using sectional models, for example SALSA (Kokkola et al., 2008; Bergman et al., 2011).

The aerosol model is coupled to a double-moment cloud microphysics scheme (Lohmann et al., 2007), and cloud droplet activation is parameterized according to Lin and Leaitch (1997). The number concentration of particles with wet radii larger than $35 \mathrm{~nm}, N_{\mathrm{a}}$ is given to the parameterization, which calculates the number of activated cloud droplets from $N_{\mathrm{a}}$, updraft velocity and cloud droplet concentration from the previous timestep. The updraft velocity is obtained from the grid-mean vertical velocity, turbulent kinetic energy and convectively available potential energy. The activation radii of $35 \mathrm{~nm}$ lies in the middle of the Aitken mode, however it is assumed that only the larger part of the log-normal mode is able to activate. Only particles in the Aitken, accumulation and coarse modes can activate into cloud droplets. The model assumes a minimum cloud droplet number concentration of $40 \mathrm{~cm}^{-3}$, which was the highest value found in a model intercomparison by Quaas et al. (2009). There is evidence that this unphysical constraint affects the aerosol indirect effect (Hoose et al., 2009), which might result in underestimation of total aerosol forcing in this study.

ECHAM5-HAM utilises monthly-mean oxidation fields of $\mathrm{OH}, \mathrm{H}_{2} \mathrm{O}_{2}, \mathrm{O}_{3}$ and $\mathrm{NO}_{2}$, which are prescribed based on simulations with the MOZART chemical transport model (Horowitz et al., 2003). $\mathrm{SO}_{2}$ is oxidized by $\mathrm{OH}$ in the gas phase and by $\mathrm{H}_{2} \mathrm{O}_{2}$ and $\mathrm{O}_{3}$ in the aqueous phase. The gas phase reactions of DMS with $\mathrm{OH}$ and $\mathrm{NO}_{3}$ are considered. The prescribed oxidant fields represent conditions of the year 2000 , but we apply them also for the pre-industrial and future simulations.

The sea-surface temperature and sea ice extent are prescribed to present-day values. We integrate the model for $5 \mathrm{yr}$ and calculate the total aerosol forcing as radiative flux perturbation (Haywood et al., 2009; Lohmann et al., 2009). The flux perturbation is calculated for total radiation (shortwave+longwave). The technique is similar to what most models used in the indirect effect intercomparison study by 
Quaas et al. (2009). Since our model setup couples aerosols with cloud microphysics, the total effect includes the direct effect, semi-direct effect, 1st indirect effect (cloud albedo), and indirect effects beyond the cloud albedo effect: although the prescribed sea-surface temperatures will keep the overall climate fixed, changes in aerosols and cloud properties can induce changes in e.g. precipitation and cloud cover.

We will conduct two sets of experiments, with and without nucleation. In simulations without nucleation both boundary layer nucleation and binary sulphuric acid-water nucleation is turned off, but other microphysical processes are left untouched (e.g. sulphuric acid and BVOC oxidation products can still condense on existing particles).

\subsection{Anthropogenic emissions}

Anthropogenic aerosol and precursor emissions are taken from the AeroCom inventories for the years 1750 and 2000 (Dentener et al., 2006). For the future we apply three of the four pathways constructed for the IPCC AR5 emission development process, namely RCP 3-PD (van Vuuren et al., 2007), RCP 4.5 (Smith and Wigley, 2006; Clarke et al., 2007; Wise et al., 2009) and RCP 8.5 (Riahi et al., 2007). The evolution of aerosols in these pathways has been presented in detail by Lamarque et al. (2011), who found a strong decrease in anthropogenic aerosols by the year 2100 . The anthropogenic emissions of aerosols and precursors are projected to be greatly reduced by the year 2100 . The emissions of $\mathrm{SO}_{2}$ will decrease from $107 \mathrm{Tg}\left(\mathrm{SO}_{2}\right) \mathrm{yr}^{-1}$ to $13-$ $26 \mathrm{Tg}\left(\mathrm{SO}_{2}\right) \mathrm{yr}^{-1}$. The emissions of $\mathrm{BC}$ will decrease from 7.8 $\mathrm{Tg} \mathrm{yr}^{-1}$ to $3.4-4.4 \mathrm{Tg} \mathrm{yr}^{-1}$, showing a narrower range of values in the year 2100 than $\mathrm{SO}_{2}$. The emissions of $\mathrm{OC}$ will decrease from $36 \mathrm{Tg} \mathrm{yr}^{-1}$ to $19-32 \mathrm{Tg} \mathrm{yr}^{-1}$. The only aerosol precursor showing a future increase is $\mathrm{NH}_{3}$, which will increase from present-day emission of $49 \mathrm{Tg} \mathrm{yr}^{-1}$ to $53-$ $82 \mathrm{Tg} \mathrm{yr}^{-1}$ due to agricultural emissions.

The shapes of number size distributions of emitted primary particles are assumed identical in all simulations, following Stier et al. (2005). The primary emissions of OC and BC from fossil-fuel and bio-fuel are assumed to have a number mean radius of $30 \mathrm{~nm}$. Wildfire emissions are assumed to lead to larger primary $\mathrm{OC}$ and $\mathrm{BC}$ particles with the number mean radius of $75 \mathrm{~nm}$. The primary emission radii are based on AeroCom recommendations (Dentener et al., 2006), but have been adapted to the log-normal setup of M7 (Stier et al., 2005). As a result, the used primary aerosol radii are larger than those suggested by AeroCom, resulting in fewer emitted primary particles. Although this has some effects on simulated number concentrations, it is not straightforward to test the sensitivity to the emission radii. Certain radii suggested by AeroCom (Dentener et al., 2006) fall in between the modes of M7, which would create undesired numerical effects in aerosol microphysics.

Due to the rapid gas-to-particle conversion near source areas, we followed Stier et al. (2005), assuming that $2.5 \%$ of all emitted $\mathrm{SO}_{2}$ (except from DMS) is converted to primary sulfate and partitioned to the Aitken, accumulation and coarse modes. None of these particles are included in the nucleation mode, even though Stevens et al. (2012) highlighted the importance of nucleation in power plant plumes.

\subsection{Natural emissions}

Natural emissions of sea salt and dust are modeled interactively in all simulations (Stier et al., 2005), hence their emission strength might differ between experiments e.g. in response to changes in the wind speed. The emissions of volcanic sulphur are identical in all the simulations performed corresponding to present-day emissions (Stier et al., 2005).

The oceanic DMS emissions are modeled interactively according to Kettle and Andreae (2000) and Nightingale et al. (2000), which results in annual global DMS emission of 23.4 $\mathrm{Tg}(\mathrm{S})$ (Stier et al., 2005). In order to test the DMS emission sensitivity part of CLAW hypothesis (Charlson et al., 1987), we performed a future scenario simulation where oceanic DMS emissions are increased by $10 \%$. The applied increase is higher than proposed in literature $(+2.4 \%$ in Ramaswamy et al., 2001, $+6.5 \%$ in Bopp et al., 2004).

For biogenic VOC emissions we consider only monoterpene emissions, which leads to an underestimation of SOA. The monoterpene emissions are prescribed monthly fields generated with the dynamic vegetation model LPJ-GUESS (Schurgers et al., 2009). Depending on whether the increasing atmospheric $\mathrm{CO}_{2}$ concentration affects monoterpene production in the same way as it does for isoprene (Schurgers et al., 2009), these emissions may remain more or less unchanged, or they increase in response to warmer climate and higher vegetation productivity. The annual global monoterpene emissions are 31,30 and $28 \mathrm{Tg}(\mathrm{C})$ for pre-industrial, present-day and future, respectively. The applied monoterpene emissions are on the lower side of values reported in the literature, ranging from 30 to $128 \mathrm{Tg}(\mathrm{C}) \mathrm{yr}^{-1}$ (Carslaw et al., 2010). To assess the responsiveness of the vegetation to increase in temperature, we performed an additional future scenario where future BVOC concentrations are increased by $50 \%$ from the base-level of $28 \operatorname{Tg}(\mathrm{C})$.

\section{Results and discussion}

\subsection{Evolution of number concentrations}

Spatial distributions and temporal changes in CN (condensation nuclei, i.e. aerosol particles with diameter $d_{\mathrm{p}}>3 \mathrm{~nm}$ ) concentrations for the three years, 1750, 2000 and 2100, are shown in Fig. 1. The upper panels show the results from simulations with nucleation turned off, indicating primary emission distribution, although condensation of $\mathrm{SO}_{2}$ and $\mathrm{BVOC}$ oxidation products make a minor contribution to CN. Pre-industrial primary emissions were low in terms of aerosol number: primary aerosols contributed significantly to 

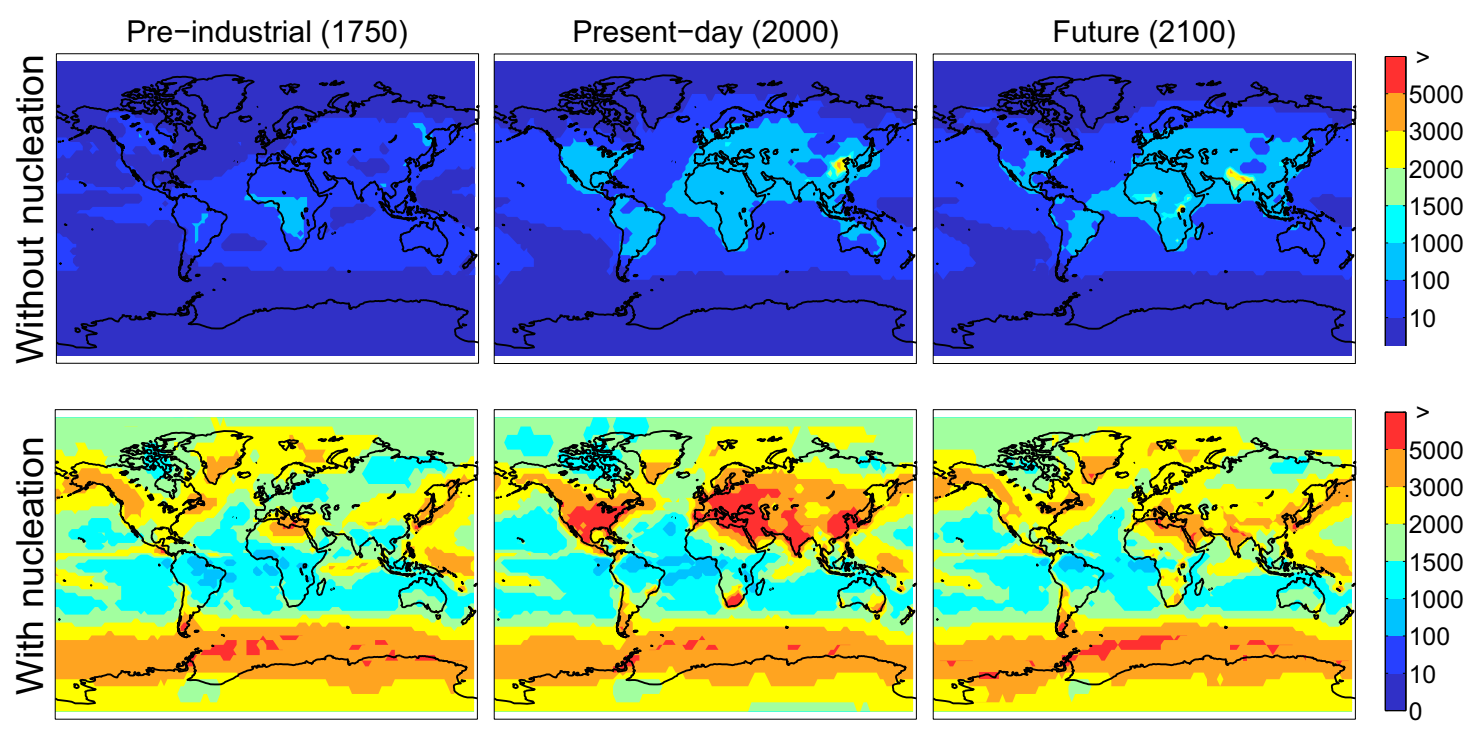

Fig. 1. Annual average concentration $\left(\mathrm{cm}^{-3}\right)$ of $\mathrm{CN}$ (condensation nuclei, aerosol particles with diameter $d_{\mathrm{p}}>3 \mathrm{~nm}$ ) in the boundary layer for the years 1750 (left), 2000 (center) and 2100 (right). The results for the year 2100 are an average from all three future emission pathways (RCP 3-PD, RCP 4.5, RCP 8.5). The upper panels show results from simulations without nucleation, and lower panels with nucleation included.

aerosol number concentration only in regions with intensive wild-land fires (Africa, South America, North-East Eurasia). The only location showing a decrease in $\mathrm{CN}$ concentration since the pre-industrial period is high-latitude boreal forests in North America and eastern Siberia, where increased fire suppression has decreased emissions (Brenkert et al., 1997). There is a clear change in the spatial distribution of primary emissions when moving to the year 2100: in general, number concentrations increase in India and Africa, and decrease elsewhere.

When aerosol nucleation is turned on (Fig. 1, lower panels), CN concentrations are increased significantly. Preindustrial anthropogenic sources of $\mathrm{SO}_{2}$ were low, hence aerosol nucleation originated mostly from natural precursors. Some of these sources can be identified in lower panels of Fig. 1: volcanoes (Philippines, areas west of New Caledonia, and southern Japan) and DMS (the band around $60^{\circ} \mathrm{S}$ ). The human impact is clearly visible under present-day conditions. Increases in primary emissions and new particle formation lead to doubled CN concentrations in US, Europe, Middle East, India, China and South Africa. There are several large areas inside these regions where $\mathrm{CN}$ concentrations are up to five times above the pre-industrial values. There are significant reductions in $\mathrm{CN}$ concentrations from present-day to the year 2100: aerosol number concentrations are decreased by 50-90\% in North America, Europe, Eastern China and South Africa. Certain equatorial regions, such as Middle Africa, show increased $\mathrm{CN}$ concentrations due to increases in wildfires.

The present-day $\mathrm{CN}$ concentrations simulated in this study are similar to those in Fig. 7e by Yu et al. (2010), who also considered activation-type nucleation in the boundary layer.
However, the land-ocean contrast in the $\mathrm{CN}$ concentration is stronger in our study. The global average $\mathrm{CN}$ concentration of $3017 \mathrm{~cm}^{-3}$ simulated here exceeds the estimate of $1063 \mathrm{~cm}^{-3}$ by Merikanto et al. (2009), but comparing the spatial CN concentration distribution modeled here to Fig. 5 in Merikanto et al. (2009) indicates that a major part of the discrepancy might be due to nucleation in the DMS belt around $60^{\circ} \mathrm{S}$ : Merikanto et al. (2009) shows CN concentrations of $<1000 \mathrm{~cm}^{-3}$ while our simulations indicate concentrations of about $3000 \mathrm{~cm}^{-3}$. Over the continents, our results seem to be relatively constistent with those by Merikanto et al. (2009).

Figure 2 presents values for pre-industrial, present-day and future CCN (cloud condensation nuclei, $d_{\mathrm{p}}>70 \mathrm{~nm}$ ) concentrations. Due to extremely low pre-industrial CCN concentrations without nucleation (upper panels), the presentday anthropogenic emissions introduce a global average increase by a factor of 4 to the boundary layer $\mathrm{CCN}$ concentration. Similarly to $\mathrm{CN}$ concentrations without nucleation, $\mathrm{CCN}$ concentrations increase in Africa and India by year 2100 , but otherwise show a decrease.

When nucleation is turned on (lower panels), the relative present-day anthropogenic effect on $\mathrm{CCN}$ concentrations is smaller. The present-day emissions lead to doubled CCN concentrations in almost all locations above land, as compared with the pre-industrial values. $\mathrm{CCN}$ concentrations increase more than fivefold in North America, central Europe, India and China, compared to pre-industrial. The presentday CCN distribution compares well with that by Spracklen et al. (2008), although our study finds slightly higher CCN concentration over the oceans. 

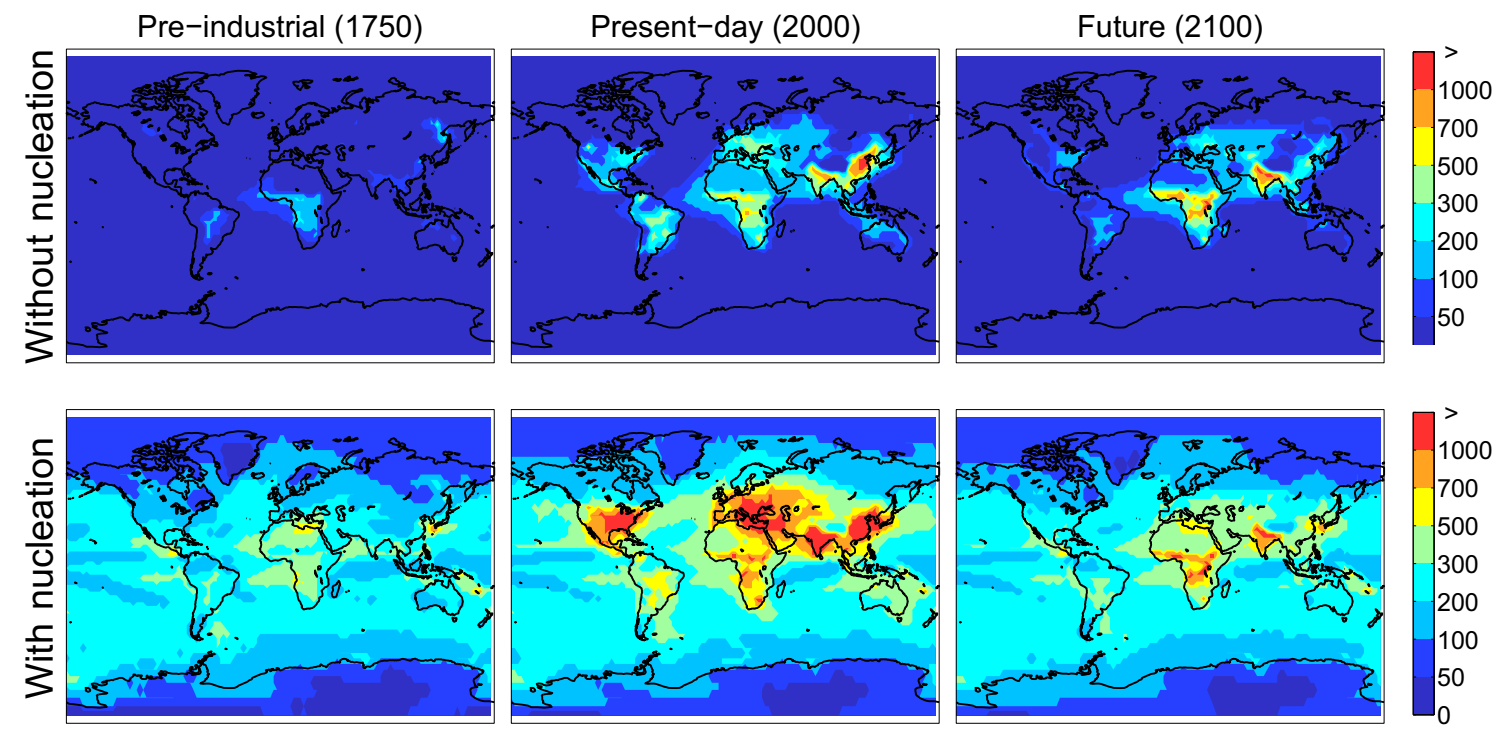

Fig. 2. Annual average concentration $\left(\mathrm{cm}^{-3}\right)$ of $\mathrm{CCN}$ (cloud condensation nuclei, $d_{\mathrm{p}}>70 \mathrm{~nm}$ ) in the boundary layer for the years 1750 (left), 2000 (center) and 2100 (right). The results for the year 2100 are an average from all three future emission pathways (RCP 3-PD, RCP 4.5, RCP 8.5). The upper panels show results from simulations without nucleation, and lower panels with nucleation included.

Table 1. Annual global average boundary layer $\mathrm{CN}$ and $\mathrm{CCN}$ concentration $\left(\mathrm{cm}^{-3}\right)$, and cloud-top $\mathrm{CDNC}\left(\mathrm{cm}^{-3}\right)$ in simulations with and without nucleation.

\begin{tabular}{cc|c|c|ccc}
\hline & & & & \multicolumn{3}{c}{ Future } \\
& Nucleation & Pre-industrial & Present-day & RCP 3-PD & RCP 4.5 & RCP 8.5 \\
\hline \multirow{2}{*}{ CN } & Off & 22 & 122 & 120 & 117 & 141 \\
& On & 2233 & 3017 & 2336 & 2426 & 2437 \\
$\mathrm{CCN}$ & Off & 21 & 86 & 69 & 64 & 77 \\
& On & 236 & 397 & 275 & 277 & 296 \\
$\mathrm{CDNC}$ & Off & 56 & 83 & 62 & 62 & 66 \\
& On & 167 & 203 & 167 & 171 & 172 \\
\hline
\end{tabular}

Even with decreasing global emissions, $\mathrm{CCN}$ concentrations in the year 2100 are still doubled to the pre-industrial values in India, Middle East, and some parts of Europe and Africa. The CCN hotspots are similar in simulations with and without nucleation. The simulated overall strong future decrease in the availability of condensation nuclei for cloud droplets are expected to lead to drastic changes in cloud properties.

The global average concentrations of $\mathrm{CN}, \mathrm{CCN}$ and cloud droplet number are summarized in Table 1 . In a preindustrial world without nucleation, the total aerosol number concentration of $22 \mathrm{~cm}^{-3}$ was mainly of CCN size. The particle number concentrations were mostly below $40 \mathrm{~cm}^{-3}$, which is the applied minimum limit for cloud droplet number concentration. Anthropogenic primary emissions lead to a factor of 5 increase in CN concentration by the year 2000 . Future $\mathrm{CN}$ concentrations from primary emissions either decrease slightly (RCP 3-PD, RCP 4.5) or increase due to increased emissions in Africa and India (RCP 8.5). Turning on nucleation in the model increases the $\mathrm{CN}$ concentration by a factor of 100, 25 and 20 in the pre-industrial, present-day and future conditions, respectively. Without nucleation, the relative increase in the $\mathrm{CN}$ concentration from pre-industrial to future is $500 \%$. Including nucleation increases the preindustrial $\mathrm{CN}$ concentration significantly, causing relative increase of only 5-9\% between pre-industrial and future.

The global 5-yr-average CDNC at the cloud-top height with and without nucleation are shown in Fig. 3. Including nucleation in the model increases the overall global CDNC by a factor of 2-3 compared with CDNC without nucleation. Our model shows a $70 \%$ increase in the boundary layer $\mathrm{CCN}$ concentration (from $236 \mathrm{~cm}^{-3}$ in year 1750 to $397 \mathrm{~cm}^{-3}$ in year 2000) and $20 \%$ increase in the cloudtop CDNC from the year 1750 to 2000 (from $167 \mathrm{~cm}^{-3}$ to $203 \mathrm{~cm}^{-3}$ ). Wang and Penner (2009) found a rather similar anthropogenic perturbation of $+85 \%$ to boundary layer CCN. Pierce and Adams (2009) conducted simulations with pre-industrial and present-day emissions and found increases 


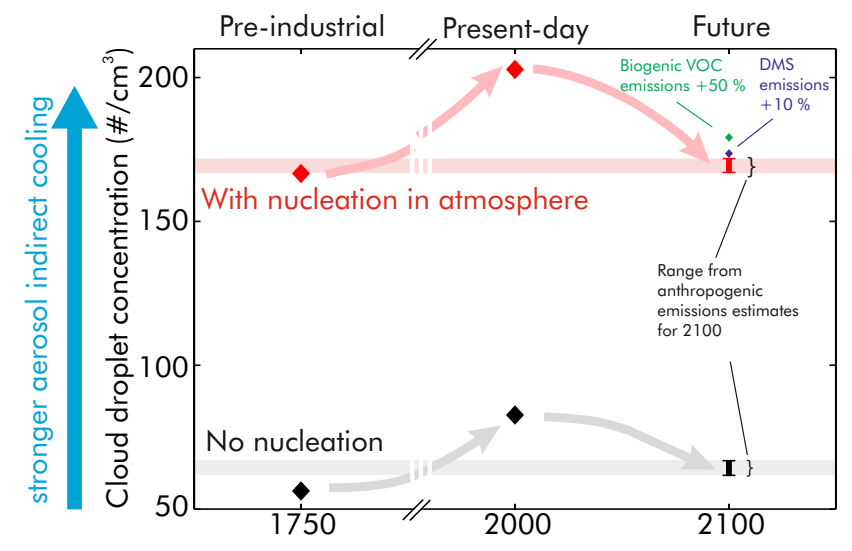

Fig. 3. Global 5-yr average cloud droplet number concentration $\left(\mathrm{cm}^{-3}\right)$ for the pre-industrial, present-day and future conditions. The cloud droplet number concentration is sampled at the cloud-top height from simulations with (red) and without (black) nucleation. Error bars and corresponding shading indicate the range in CDNC due to different future anthropogenic emission pathways. Additional simulations with $+50 \%$ biogenic VOC emissions (green) and $+10 \%$ oceanic DMS emissions (blue) are simulated with the anthropogenic emission projection RCP 4.5.

of $+220 \%$ and $+200 \%$ in the tropospheric $\mathrm{CCN}(0.2 \%)$ concentration with binary and ternary nucleation, respectively. The CDNC in the altitude range $300-1000 \mathrm{~m}$ was found to increase from $145 \mathrm{~cm}^{-3}$ (year 1850) to $240 \mathrm{~cm}^{-3}$ (year 1750) by Merikanto et al. (2010), which is much more than the CDNC increase found in our study (but identical to the $70 \%$ increase we found for the $\mathrm{CCN}$ concentration). Spracklen et al. (2008) found a $10 \%$ increase in the $\mathrm{CCN}(0.2 \%)$ concentration and $20 \%$ increase in $\mathrm{CCN}(1.0 \%)$ concentration due boundary layer nucleation when using the same activation coefficient. Although our results presented here compare simulations with nucleation turned off completely, our model shows an increase of about $20-30 \%$ in the boundary layer $\mathrm{CCN}$ due to activation-type nucleation. The sensitivity of our modeled CCN and CDNC to present-day anthropogenic perturbation seems to be consistent with earlier literature, although our result is on the smaller side. This might be due to overestimation of the pre-industrial $\mathrm{CCN}$ and CDNC due to nucleation. Also the minimum CDNC of $40 \mathrm{~cm}^{-3}$ affects the pre-industrial CDNC, and the relative changes in CDNC.

Figure 3 also shows that the reductions in primary aerosol and aerosol precursor emissions by the year 2100 lead to a strong decrease in CDNC. In simulations without nucleation, the decrease is $17 \mathrm{~cm}^{-3}(22 \%)$. When nucleation is turned on, the relative decrease is smaller $(16 \%)$, which would indicate that nucleation actually slows the decrease in cloud albedo. The CDNC in the year 2100 ranges from $167 \mathrm{~cm}^{-3}$ to $172 \mathrm{~cm}^{-3}$ (red shading in Fig. 3), showing very little variation due to anthropogenic emission uncertainties. It should be noted that without nucleation, the CDNC in the year 2100 is still $15 \%$ higher than in year 1750, while the future CDNC

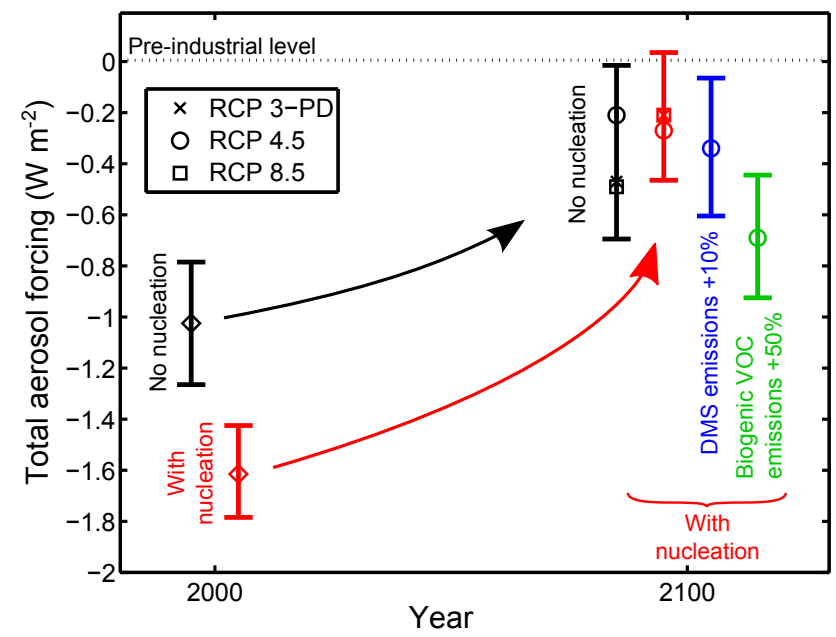

Fig. 4. Total aerosol forcing $\left(\mathrm{W} \mathrm{m}^{-2}\right)$ for the years 2000 and 2100. Additional simulations with $+50 \%$ biogenic VOC emissions (green) and $+10 \%$ oceanic DMS emissions (blue) are simulated with the anthropogenic emission projection RCP 4.5. The markers represent average forcings for present-day $(\diamond)$, RCP 3-PD $(\times)$, RCP $4.5(\bigcirc)$ and RCP $8.5(\square)$. The errorbars correspond to the range of one standard deviation, calculated from variation during 5 -yr simulation.

in nucleation simulations it is only $2 \%$ higher than in preindustrial period.

The climate feedback simulations show a clear increase in CDNC, $+2 \%$ and $+5 \%$ for an emission increase of $+10 \%$ DMS and $+50 \%$ BVOC, respectively. The two experiments work in very different ways: the increase in DMS emission leads to increase in both nucleation and aerosol growth over oceans, whereas the increase in BVOC emission only provides more growth for particles over land.

\subsection{Total aerosol forcing}

Figure 4 shows the total anthropogenic aerosol forcing for the years 2000 and 2100. The results clearly indicate how accounting for atmospheric nucleation is critical for aerosol forcing calculations. In the present-day atmosphere, including new particle formation increases the magnitude of the total aerosol forcing from $-1.03 \mathrm{~W} \mathrm{~m}^{-2}$ to $-1.61 \mathrm{~W} \mathrm{~m}^{-2}$, indicating more cooling from anthropogenic aerosols. Our present-day forcing estimates are within the $90 \%$ confidence range by (Forster et al., 2007), from -2.2 to $-0.5 \mathrm{~W} \mathrm{~m}^{-2}$, which does not consider the cloud lifetime effect included here. Hansen et al. (2011) used observations of the ocean heat uptake and global temperature change, and found the aerosol climate forcing at 2010 to be $-1.6 \pm 0.3 \mathrm{~W} \mathrm{~m}^{-2}$, which is identical to our study. The total aerosol forcing of $-1.61 \mathrm{~W} \mathrm{~m}^{-2}$ simulated here is also similar to $-1.57 \pm$ $0.66 \mathrm{~W} \mathrm{~m}^{-2}$ obtained for the total aerosol forcing averaged over ten global models by Quaas et al. (2009). While nucleation increases the present-day aerosol forcing, more 
importantly the change in aerosol forcing from present-day to year 2100 is $+1.3-1.4 \mathrm{~W} \mathrm{~m}^{-2}$ when nucleation is considered, while it is only $+0.5-0.8 \mathrm{~W} \mathrm{~m}^{-2}$ without nucleation. It should be noted that the minimum CDNC of $40 \mathrm{~cm}^{-3}$ applied here can be considered rather high especially for preindustrial clouds, hence causing an underestimation of the anthropogenic forcing (Hoose et al., 2009).

All simulations performed in this study use coupled aerosol-cloud microphysics and prescribed sea-surface temperatures. Calculation of aerosol direct forcing would require fixing of meteorology, i.e. nudging the model. To give some idea on the contribution of direct/indirect effects on the simulated total aerosol effect, we diagnosed the clear-sky top-ofatmosphere shortwave aerosol direct forcing. We can compare these forcings to Lamarque et al. (2011), who used the same emission pathways and calculated the clear-sky top-ofatmosphere shortwave aerosol forcing. We can also compare our present-day forcing to AeroCom intercomparison study by Schulz et al. (2006). Both our present-day simulations show a $-0.70 \mathrm{~W} \mathrm{~m}^{-2}$ clear-sky forcing, which is almost identical to $-0.68 \pm 0.28 \mathrm{~W} \mathrm{~m}^{-2}$ in Schulz et al. (2006) and slightly smaller than $-0.8 \mathrm{~W} \mathrm{~m}^{-2}$ in Lamarque et al. (2011). In simulations without nucleation, the direct aerosol forcing is decreased to $-0.26 \mathrm{~W} \mathrm{~m}^{-2}$ (RCP 3-PD), $-0.22 \mathrm{~W} \mathrm{~m}^{-2}$ (RCP 4.5) and $-0.28 \mathrm{~W} \mathrm{~m}^{-2}$ (RCP 8.5) by the year 2100 . These findings are similar to Lamarque et al. (2011), who found a future aerosol direct forcings of $-0.24 \mathrm{~W} \mathrm{~m}^{-2}$ (RCP $3-\mathrm{PD}),-0.24 \mathrm{~W} \mathrm{~m}^{-2}$ (RCP 4.5 ) and $-0.37 \mathrm{~W} \mathrm{~m}^{-2}$ (RCP 8.5). The slight discrepancy is partly explained by the future increase in ammonium nitrate forcing by $0-0.05 \mathrm{~W} \mathrm{~m}^{-2}$, which is not considered in our study. Including nucleation in the model decreases the future clear-sky aerosol direct forcing to $-0.05 \mathrm{~W} \mathrm{~m}^{-2}$. In the AeroCom intercomparison (Schulz et al., 2006), the present-day clear-sky direct forcing of $-0.68 \pm 0.28$ resulted in an all-sky direct forcing of $-0.22 \mathrm{~W} \mathrm{~m}^{-2}$, hence it is very likely that a major part of the total aerosol forcing shown in this study is due to aerosol indirect effects.

The applied emission pathways show strong changes in anthropogenic emissions of black carbon (BC, 40-60\% reduction) and organic carbon (OC, 10-60\% reduction). It has been shown that a $50 \%$ reduction in the primary BC/OC mass and number emissions alone would lead to $+0.19 \mathrm{~W} \mathrm{~m}^{-2}$ forcing in present-day climate (Chen et al., 2010), when taking into account both the cooling from reduced $\mathrm{BC}\left(-0.12 \mathrm{~W} \mathrm{~m}^{-2}\right)$ and simultaneous warming from decreased CDNC $\left(+0.31 \mathrm{~W} \mathrm{~m}^{-2}\right)$. The findings by Lamarque et al. (2011) indicate a $0.06-0.09 \mathrm{~W} \mathrm{~m}^{-2}$ positive clear-sky forcing from reduced $\mathrm{BC}$, when applying the same emission pathways as in this study. Hence, the BC/OC reduction could explain a major part of the simulated future warming without nucleation $\left(+0.64 \mathrm{~W} \mathrm{~m}^{-2}\right)$.

Kloster et al. (2008) showed that even a $+1.13 \mathrm{~W} \mathrm{~m}^{-2}$ warming until 2030 from the reduced aerosol load would be plausible under a "maximum feasible reduction" sce- nario. Although their present-day total aerosol forcing $\left(-2.00 \mathrm{~W} \mathrm{~m}^{-2}\right)$ is stronger compared with our simulations, the applied $80 \%$ reduction in anthropogenic $\mathrm{SO}_{2}$ is comparable to future scenarios used here.

While the simulated present-day total aerosol forcing $\left(-1.61 \mathrm{~W} \mathrm{~m}^{-2}\right)$ is rather close (but of opposite signal) to the present-day forcing of $\mathrm{CO}_{2}\left(+1.66 \mathrm{~W} \mathrm{~m}^{-2}\right.$, Forster et al., 2007), the future warming from applied air pollution control and the resulting decrease in aerosol effects (a change of $+1.38 \mathrm{~W} \mathrm{~m}^{-2}$ in total aerosol forcing, when averaged over future scenarios) would accelerate the rate of climate warming in response to increasing greenhouse gas concentrations. For example, in the scenario of RCP 3-PD (van Vuuren et al., 2007) the $\mathrm{CO}_{2}$ forcing is estimated to increase from $+1.5 \mathrm{~W} \mathrm{~m}^{-2}$ (year 2000) to $+2.3 \mathrm{~W} \mathrm{~m}^{-2}$ (year 2100), hence the warming resulting from reduced aerosol forcing alone might be more than that due to $\mathrm{CO}_{2}$ concentration over the same time period.

Could changes in natural aerosol precursors counteract the effects of anthropogenic emission changes? This seems unlikely, as shown in Fig. 4. The simulation with $+50 \%$ BVOC emission shows increased particle growth from oxidized organics, leading to $5 \%$ increase in CDNC and finally an additional negative forcing of $-0.46 \mathrm{~W} \mathrm{~m}^{-2}$. Similarly, an increase of $+10 \%$ in DMS emission can only add an extra cooling of $-0.12 \mathrm{~W} \mathrm{~m}^{-2}$ to the future aerosol forcing. It should be noted, however, that the effect of these additional emissions is not negligible, and that there might be other processes and feedbacks involved.

\section{Conclusions}

Our analysis provides evidence on how the present-day climate forcing by aerosol particles is controlled strongly by atmospheric new particle formation. This is due to a favourable combination of anthropogenic sulphur and biogenic organic vapour emissions, which together produce effectively new cloud condensation nuclei that enhance the negative cloud forcing.

We have shown that even though the total number concentration of primary aerosols might stay constant or even increase slightly by the year 2100 , the strong reduction in anthropogenic $\mathrm{SO}_{2}$ emissions will lead to less aerosol nucleation, rendering the total number concentrations close to pre-industrial values. More importantly, due to the simulated strong coupling of $\mathrm{SO}_{2}$ and $\mathrm{CCN}$, the future cloud droplet concentrations will be decreased to almost pre-industrial concentrations. Hence, the current cooling effect by aerosol particles (total aerosol forcing of $-1.61 \mathrm{~W} \mathrm{~m}^{-2}$ ) will be reduced close to zero $\left(-0.23 \mathrm{~W} \mathrm{~m}^{-2}\right)$ by 2100 . The two climate feedbacks studied (increase in either DMS or BVOC) show increased CDNC and result in additional negative forcing, yet they can not compensate for the effects of decreasing anthropogenic emissions. The suppression of future aerosol forcing, if true, would lead to even a larger warming of 
climate than what is expected based on increased greenhouse gas concentrations (Andreae et al., 2005).

Acknowledgements. We thank the reviewers Peter Adams and Jeffrey Pierce for providing useful suggestions for improvements in the manuscript. We thank Kai Zhang for providing the RCP emission fields for ECHAM5-HAM. We thank the Finnish IT center for science (CSC) for technical support and computing time. The financial support by the Academy of Finland Centre of Excellence program (project no. 1118615) and EU-project EUCAARI (European Integrated project on Aerosol Cloud Climate and Air Quality interactions, project no. 036833-2) is gratefully acknowledged. A. Arneth acknowledges support from the Swedish Research Councils Formas and Vetenskapsrådet. M. K. acknowledges support from the European Research Counsil Advanced Grant (no. 227463).

Edited by: M. C. Facchini

\section{References}

Albrecht, B. A.: Aerosols, cloud microphysics, and fractional cloudiness, Science, 245, 1227-1230, 1989.

Andreae, M. O., Jones, C. D., and Cox, P. M.: Strong present-day aerosol cooling implies a hot future, Nature, 435, 1187-1190, 2005.

Arneth, A., Niinemets, Ü., Pressley, S., Bäck, J., Hari, P., Karl, T., Noe, S., Prentice, I. C., Serça, D., Hickler, T., Wolf, A., and Smith, B.: Process-based estimates of terrestrial ecosystem isoprene emissions: incorporating the effects of a direct $\mathrm{CO}_{2}$-isoprene interaction, Atmos. Chem. Phys., 7, 31-53, doi:10.5194/acp-7-31-2007, 2007.

Bergman, T., Kerminen, V.-M., Korhonen, H., Lehtinen, K. J., Makkonen, R., Arola, A., Mielonen, T., Romakkaniemi, S., Kulmala, M., and Kokkola, H.: Evaluation of the sectional aerosol microphysics module SALSA implementation in ECHAM5HAM aerosol-climate model, Geosci. Model Dev. Discuss., 4, 3623-3690, doi:10.5194/gmdd-4-3623-2011, 2011.

Bopp, L., Boucher, O., Aumont, O., Belviso, S., Dufresne, J.-L., Pham, M., and Monfray, P.: Will marine DMS emissions amplify or alleviate global warming? - A model study, Cana. J. Fish. Aquat. Sci., 61, 826-835, 2004.

Brenkert, A., Marland, G., Boden, T., Andres, R., and Olivier, J.: CO2 emissions from fossil fuel burning: Comparisons of 1990 gridded maps and an update to 1995, EOS Transactions, AGU, 78, 1997.

Carslaw, K. S., Boucher, O., Spracklen, D. V., Mann, G. W., Rae, J. G. L., Woodward, S., and Kulmala, M.: A review of natural aerosol interactions and feedbacks within the Earth system, Atmos. Chem. Phys., 10, 1701-1737, doi:10.5194/acp-10-17012010, 2010.

Charlson, R. J., Lovelock, J. E., Andreae, M. O., and Warren, S. G. Oceanic phytoplankton, atmospheric sulphur, cloud albedo and climate, Nature, 326, 655-661, 1987.

Chen, W.-T., Lee, Y. H., Adams, P. J., Nenes, A., and Seinfeld, J. H.: Will black carbon mitigation dampen aerosol indirect forcing?, Geophys. Res. Lett., 37, L09801, doi:10.1029/2010GL042886, 2010.

Clarke, L., Edmonds, J., Jacoby, H., Pitcher, H., Reilly, J., and Richels, R.: Scenarios of Greenhouse Gas Emissions and Atmospheric Concentrations, Sub-report 2.1A of Synthesis and As- sessment Product 2.1 by the U.S. Climate Change Science Program and the Subcommittee on Global Change Research, Department of Energy, Office of Biological \& Environmental Research, Washington, 7 D.C., USA, 154 pp, 2007.

Dentener, F., Kinne, S., Bond, T., Boucher, O., Cofala, J., Generoso, S., Ginoux, P., Gong, S., Hoelzemann, J. J., Ito, A., Marelli, L., Penner, J. E., Putaud, J.-P., Textor, C., Schulz, M., van der Werf, G. R., and Wilson, J.: Emissions of primary aerosol and precursor gases in the years 2000 and 1750 prescribed data-sets for AeroCom, Atmos. Chem. Phys., 6, 4321-4344, doi:10.5194/acp6-4321-2006, 2006.

Forster, P., Ramaswamy, V., Artaxo, P., Berntsen, T., Betts, R., Fahey, D., Haywood, J., Lean, J., Lowe, D., Myhre, G., Nganga, J., Prinn, R., Raga, G., Schulz, M., and Van Dorland, R.: Radiative Forcing of Climate Change, in: Climate Change 2007: the Physical Science Basis, Contribution of Working Group I to the Fourth Assessment Report of the Intergovernmental Panel on Climate Change, edited by: Solomon, S., Qin, D., Manning, M., Chen, Z., Marquis, M., Averyt, K. B., Tignor, M., and Miller, H., Cambridge Univ. Press, New York, 129-234, 2007.

Hansen, J., Sato, M., Kharecha, P., and von Schuckmann, K.: Earth's energy imbalance and implications, Atmos. Chem. Phys., 11, 13421-13449, doi:10.5194/acp-11-13421-2011, 2011.

Haywood, J. M., Donner, L. J., Jones, A., and Golaz, J.-C.: Global indirect radiative forcing caused by aerosols: IPCC (2007) and beyond, in: Clouds in the Perturbed Climate System, edited by: Heintzenberg, J. and Charlson, R. J., MIT Press, Cambridge, 2009.

Hoose, C., Kristjánsson, J. E., Iversen, T., Kirkevåg, A., Seland, Ø., and Gettelman, A.: Constraining cloud droplet number concentration in GCMs suppresses the aerosol indirect effect, Geophys. Res. Lett., 36, L12807, doi:10.1029/2009GL038568, 2009.

Horowitz, L. W., Walters, S., Mauzerall, D. L., Emmons, L. K., Rasch, P. J., Granier, C., Tie, X., Lamarque, J.-F., Schultz, M. G., Tyndall, G. S., Orlando, J. J., and Brasseur, G. P.: A global simulation of tropospheric ozone and related tracers: Description and evaluation of MOZART, version 22, J. Geophys. Res., 108, 4784, doi:10.1029/2002JD002853, 2003.

Jimenez, J. L., Canagaratna, M. R., Donahue, N. M., Prevot, A. S. H., Zhang, Q., Kroll, J. H., DeCarlo, P. F., Allan, J. D., Coe, H., Ng, N. L., Aiken, A. C., Docherty, K. S., Ulbrich, I. M., Grieshop, A. P., Robinson, A. L., Duplissy, J., Smith, J. D., Wilson, K. R., Lanz, V. A., Hueglin, C., Sun, Y. L., Tian, J., Laaksonen, A., Raatikainen, T., Rautiainen, J., Vaattovaara, P., Ehn, M., Kulmala, M., Tomlinson, J. M., Collins, D. R., Cubison, M. J., Dunlea, E. J., Huffman, J. A., Onasch, T. B., Alfarra, M. R., Williams, P. I., Bower, K., Kondo, Y., Schneider, J., Drewnick, F., Borrmann, S., Weimer, S., Demerjian, K., Salcedo, D., Cottrell, L., Griffin, R., Takami, A., Miyoshi, T., Hatakeyama, S., Shimono, A., Sun, J. Y., Zhang, Y. M., Dzepina, K., Kimmel, J. R., Sueper, D., Jayne, J. T., Herndon, S. C., Trimborn, A. M., Williams, L. R., Wood, E. C., Middlebrook, A. M., Kolb, C. E., Baltensperger, U., and Worsnop, D. R.: Evolution of Organic Aerosols in the Atmosphere, Science, 326, 1525-1529, 2009.

Kazil, J., Stier, P., Zhang, K., Quaas, J., Kinne, S., O’Donnell, D., Rast, S., Esch, M., Ferrachat, S., Lohmann, U., and Feichter, J.: Aerosol nucleation and its role for clouds and Earth's radiative forcing in the aerosol-climate model ECHAM5-HAM, Atmos. Chem. Phys., 10, 10733-10752, doi:10.5194/acp-10- 
10733-2010, 2010.

Kerminen, V.-M. and Kulmala, M.: Analytical formulae connecting the real and the apparent nucleation rate and the nuclei number concentration for atmospheric nucleation events, J. Aerosol Sci., 33, 609-622, 2002.

Kerminen, V.-M., Lihavainen, H., Komppula, M., Viisanen, Y., and Kulmala, M.: Direct observational evidence linking atmospheric aerosol formation and cloud droplet activation, Geophys. Res. Lett., 32, L14803, doi:10.1029/2005GL023130, 2005.

Kerminen, V.-M., Petäjä, T., Manninen, H. E., Paasonen, P., Nieminen, T., Sipilä, M., Junninen, H., Ehn, M., Gagné, S., Laakso, L., Riipinen, I., Vehkamäki, H., Kurten, T., Ortega, I. K., Dal Maso, M., Brus, D., Hyvärinen, A., Lihavainen, H., Leppä, J., Lehtinen, K. E. J., Mirme, A., Mirme, S., Hõrrak, U., Berndt, T., Stratmann, F., Birmili, W., Wiedensohler, A., Metzger, A., Dommen, J., Baltensperger, U., Kiendler-Scharr, A., Mentel, T. F., Wildt, J., Winkler, P. M., Wagner, P. E., Petzold, A., Minikin, A., Plass-Dülmer, C., Pöschl, U., Laaksonen, A., and Kulmala, M.: Atmospheric nucleation: highlights of the EUCAARI project and future directions, Atmos. Chem. Phys., 10, 10829-10848, doi:10.5194/acp-10-10829-2010, 2010.

Kettle, A. and Andreae, M.: Flux of the dimethylsulfide from the oceans: A comparison of updated data sets and flux models, J. Geophys. Res., 105, 26793-26808, 2000.

Kloster, S., Dentener, F., Feichter, J., Raes, F., van Aardenne, J., Roeckner, E., Lohmann, U., Stier, P., and Swart, R.: Influence of future air pollution mitigation strategies on total aerosol radiative forcing, Atmos. Chem. Phys., 8, 6405-6437, doi:10.5194/acp-86405-2008, 2008.

Kokkola, H., Korhonen, H., Lehtinen, K. E. J., Makkonen, R., Asmi, A., Järvenoja, S., Anttila, T., Partanen, A.-I., Kulmala, M., Järvinen, H., Laaksonen, A., and Kerminen, V.-M.: SALSA - a Sectional Aerosol module for Large Scale Applications, Atmos. Chem. Phys., 8, 2469-2483, doi:10.5194/acp-8-2469-2008, 2008.

Kulmala, M., Vehkamäki, H., Petäjä, T., Dal Maso, M., Lauri, A., Kerminen, V.-M., Birmili, W., and McMurry, P. H.: Formation and growth rates of ultrafine atmospheric particles: A review of observations, J. Aerosol Sci., 35, 143-176, 2004.

Kulmala, M., Lehtinen, K. E. J., and Laaksonen, A.: Cluster activation theory as an explanation of the linear dependence between formation rate of $3 \mathrm{~nm}$ particles and sulphuric acid concentration, Atmos. Chem. Phys., 6, 787-793, doi:10.5194/acp-6-787-2006, 2006.

Lamarque, J.-F., Kyle, G., Meinshausen, M., Riahi, K., Smith, S., van Vuuren, D., Conley, A., and Vitt, F.: Global and regional evolution of short-lived radiatively-active gases and aerosols in the representative concentration pathways, Climatic Change, 109, 191-212, doi:10.1007/s10584-011-0155-0, 2011.

Lathière, J., Hauglustaine, D. A., De Noblet-Ducoudré, N., Krinner, G., and Folberth, G. A.: Past and future changes in biogenic volatile organic compound emissions simulated with a global dynamic vegetation model, Geophys. Res. Lett., 32, L20818, doi:10.1029/2005GL024164, 2005.

Lihavainen, H., Kerminen, V.-M., Komppula, M., Hatakka, J., Aaltonen, V., Kulmala, M., and Viisanen, Y.: Production of potential cloud condensation nuclei associated with atmospheric newparticle formation in northern Finland, J. Geophys. Res., 108, 4782, doi:10.1029/2003JD003887, 2003.
Lin, H. and Leaitch, W. R.: Development of an in-cloud aerosol activation parameterization for climate modelling, in: Proceedings of the WMO Workshop on Measurement of Cloud Properties for Forecasts of Weather, Air Quality and Climate, World Meteorol. Organ., Geneva, 328-335, 1997.

Lohmann, U., Stier, P., Hoose, C., Ferrachat, S., Kloster, S., Roeckner, E., and Zhang, J.: Cloud microphysics and aerosol indirect effects in the global climate model ECHAM5-HAM, Atmos. Chem. Phys., 7, 3425-3446, doi:10.5194/acp-7-3425-2007, 2007.

Lohmann, U., Rotstayn, L., Storelvmo, T., Jones, A., Menon, S., Quaas, J., Ekman, A. M. L., Koch, D., and Ruedy, R.: Total aerosol effect: radiative forcing or radiative flux perturbation?, Atmos. Chem. Phys., 10, 3235-3246, doi:10.5194/acp-10-32352010, 2010.

Lu, Z., Zhang, Q., and Streets, D. G.: Sulfur dioxide and primary carbonaceous aerosol emissions in China and India, 1996-2010, Atmos. Chem. Phys., 11, 9839-9864, doi:10.5194/acp-11-98392011, 2011.

Makkonen, R., Asmi, A., Korhonen, H., Kokkola, H., Järvenoja, S., Räisänen, P., Lehtinen, K. E. J., Laaksonen, A., Kerminen, V.M., Järvinen, H., Lohmann, U., Bennartz, R., Feichter, J., and Kulmala, M.: Sensitivity of aerosol concentrations and cloud properties to nucleation and secondary organic distribution in ECHAM5-HAM global circulation model, Atmos. Chem. Phys., 9, 1747-1766, doi:10.5194/acp-9-1747-2009, 2009.

Merikanto, J., Spracklen, D. V., Mann, G. W., Pickering, S. J., and Carslaw, K. S.: Impact of nucleation on global CCN, Atmos. Chem. Phys., 9, 8601-8616, doi:10.5194/acp-9-8601-2009, 2009.

Merikanto, J., Spracklen, D. V., Pringle, K. J., and Carslaw, K. S.: Effects of boundary layer particle formation on cloud droplet number and changes in cloud albedo from 1850 to 2000, Atmos. Chem. Phys., 10, 695-705, doi:10.5194/acp-10-695-2010, 2010.

Metzger, A., Verheggen, B., Dommen, J., Duplissy, J., Prevot, A. S., Weingartner, E., Riipinen, I., Kulmala, M., Spracklen, D. V., and Carslaw, K. S.: Evidence for the role of organics in aerosol particle formation under atmospheric conditions, Proc. Nat. Acad. Sci., 107, doi:10.1073/pnas.0911330107, 2010.

Moss, R. H., Edmonds, J. A., Hibbard, K. A., Manning, M. R., Rose, S. K., van Vuuren, D. P., Carter, T. R., Emori, S., Kainuma, M., Kram, T., Meehl, G. A., Mitchell, J. F., Nakicenovic, N., Riahi, K., Smith, S. J., Stouffer, R. J., Thomson, A. M., Weyant, J. P., and Wilbanks, T. J.: The next generation of scenarios for climate change research and assessment, Nature, 463, 747-756, 2010.

Nightingale, P., Malin, G., Law, C., Watson, A., Liss, P., Liddicoat, M., Boutin, J., and Upstill-Goddard, R.: In situ evaluation of airsea gas exchange parameterizations using novel conservative and volatile tracers, Global Biogeochem. Cy., 14, 373-387, 2000.

Paasonen, P., Nieminen, T., Asmi, E., Manninen, H. E., Petäjä, T., Plass-Dülmer, C., Flentje, H., Birmili, W., Wiedensohler, A., Hõrrak, U., Metzger, A., Hamed, A., Laaksonen, A., Facchini, M. C., Kerminen, V.-M., and Kulmala, M.: On the roles of sulphuric acid and low-volatility organic vapours in the initial steps of atmospheric new particle formation, Atmos. Chem. Phys., 10, 11223-11242, doi:10.5194/acp-10-11223-2010, 2010.

Pierce, J. R. and Adams, P. J.: Uncertainty in global CCN concentrations from uncertain aerosol nucleation and primary emission 
rates, Atmos. Chem. Phys., 9, 1339-1356, doi:10.5194/acp-91339-2009, 2009.

Quaas, J., Ming, Y., Menon, S., Takemura, T., Wang, M., Penner, J. E., Gettelman, A., Lohmann, U., Bellouin, N., Boucher, O., Sayer, A. M., Thomas, G. E., McComiskey, A., Feingold, G., Hoose, C., Kristjánsson, J. E., Liu, X., Balkanski, Y., Donner, L. J., Ginoux, P. A., Stier, P., Grandey, B., Feichter, J., Sednev, I., Bauer, S. E., Koch, D., Grainger, R. G., Kirkevåg, A., Iversen, T., Seland, Ø., Easter, R., Ghan, S. J., Rasch, P. J., Morrison, H., Lamarque, J.-F., Iacono, M. J., Kinne, S., and Schulz, M.: Aerosol indirect effects - general circulation model intercomparison and evaluation with satellite data, Atmos. Chem. Phys., 9, 8697-8717, doi:10.5194/acp-9-8697-2009, 2009.

Ramaswamy, V., Boucher, O., Haigh, J., Hauglustaine, D., Haywood, J., Myhre, G., Nakajima, T., Shi, G. Y., and Solomon, S.: Radiative Forcing of Climate Change, in: Climate Change 2001: The Scientific Basis. Contribution of working group I to the Third Assessment Report of the Intergovernmental Panel on Climate Change, edited by: Houghton, J. T., Ding, Y., Griggs, D. J., Noguer, M., van der Linden, P. J., Dai, X., Maskell, K., and Johnson, C. A., Cambridge Univ. Press, New York, 349-416, 2001.

Riahi, K., Gruebler, A., and Nakicenovic, N.: Scenarios of longterm socio-economic and environmental development under climate stabilization, Technol. Forecast. Soc., 74, 887-935, 2007.

Schulz, M., Textor, C., Kinne, S., Balkanski, Y., Bauer, S., Berntsen, T., Berglen, T., Boucher, O., Dentener, F., Guibert, S., Isaksen, I. S. A., Iversen, T., Koch, D., Kirkevåg, A., Liu, X., Montanaro, V., Myhre, G., Penner, J. E., Pitari, G., Reddy, S., Seland, Ø., Stier, P., and Takemura, T.: Radiative forcing by aerosols as derived from the AeroCom present-day and pre-industrial simulations, Atmos. Chem. Phys., 6, 5225-5246, doi:10.5194/acp-6-5225-2006, 2006.

Schurgers, G., Arneth, A., Holzinger, R., and Goldstein, A. H.: Process-based modelling of biogenic monoterpene emissions combining production and release from storage, Atmos. Chem. Phys., 9, 3409-3423, doi:10.5194/acp-9-3409-2009, 2009.

Sipilä, M., Berndt, T., Petäjä, T., Brus, D., Vanhanen, J., Stratmann, F., Patokoski, J., Mauldin III, R. L., Hyvärinen, H., Lihavainen, H., and Kulmala, M.: The Role of Sulfuric Acid in Atmospheric Nucleation, Science, 327, 1243-1246, 2010.

Smith, S. J. and Wigley, T. M. L.: Multi-Gas Forcing Stabilization with the MiniCAM, Energy Journal, Special Issue \#3, 373-391, 2006.

Smith, S. J., van Aardenne, J., Klimont, Z., Andres, R. J., Volke, A., and Delgado Arias, S.: Anthropogenic sulfur dioxide emissions: 1850-2005, Atmos. Chem. Phys., 11, 1101-1116, doi:10.5194/acp-11-1101-2011, 2011.

Spracklen, D. V., Carslaw, K. S., Kulmala, M., Kerminen, V.-M., Mann, G. W., and Sihto, S.-L.: The contribution of boundary layer nucleation events to total particle concentrations on regional and global scales, Atmos. Chem. Phys., 6, 5631-5648, doi:10.5194/acp-6-5631-2006, 2006.

Spracklen, D. V., Carslaw, K. S., Kulmala, M., Kerminen, V.-M., Sihto, S.-L., Riipinen, I., Merikanto, J., Mann, G. W., Chipperfield, M. P., Wiedensohler, A., Birmili, W., and Lihavainen, H.: Contribution of particle formation to global cloud condensation nuclei concentrations, Geophys. Res. Lett., 35, L06808, doi:10.1029/2007GL033038, 2008.
Spracklen, D. V., Carslaw, K. S., Merikanto, J., Mann, G. W., Reddington, C. L., Pickering, S., Ogren, J. A., Andrews, E., Baltensperger, U., Weingartner, E., Boy, M., Kulmala, M., Laakso, L., Lihavainen, H., Kivekäs, N., Komppula, M., Mihalopoulos, N., Kouvarakis, G., Jennings, S. G., O’Dowd, C., Birmili, W., Wiedensohler, A., Weller, R., Gras, J., Laj, P., Sellegri, K., Bonn, B., Krejci, R., Laaksonen, A., Hamed, A., Minikin, A., Harrison, R. M., Talbot, R., and Sun, J.: Explaining global surface aerosol number concentrations in terms of primary emissions and particle formation, Atmos. Chem. Phys., 10, 4775-4793, doi:10.5194/acp-10-4775-2010, 2010.

Stevens, R. G., Pierce, J. R., Brock, C. A., Reed, M. K., Crawford, J. H., Holloway, J. S., Ryerson, T. B., Huey, L. G., and Nowak, J. B.: Nucleation and growth of sulfate aerosol in coal-fired power plant plumes: sensitivity to background aerosol and meteorology, Atmos. Chem. Phys., 12, 189-206, doi:10.5194/acp12-189-2012, 2012.

Stier, P., Feichter, J., Kinne, S., Kloster, S., Vignati, E., Wilson, J., Ganzeveld, L., Tegen, I., Werner, M., Balkanski, Y., Schulz, M., Boucher, O., Minikin, A., and Petzold, A.: The aerosolclimate model ECHAM5-HAM, Atmos. Chem. Phys., 5, 1125 1156, doi:10.5194/acp-5-1125-2005, 2005.

Stier, P., Feichter, J., Roeckner, E., Kloster, S., and Esch, M.: The evolution of the global aerosol system in a transient climate simulation from 1860 to 2100, Atmos. Chem. Phys., 6, 3059-3076, doi:10.5194/acp-6-3059-2006, 2006.

Twomey, S.: Pollution and the planetary albedo, Atmos. Environ., 8, 1251-1256, 1974.

van Vuuren, D. P., den Elzen, M. G. J., Lucas, P. L., Eickhout, B., Strengers, B. J., van Ruijven, B., Wonink, S., and van Houdt, R.: Stabilizing greenhouse gas concentrations at low levels: an assessment of reduction strategies and costs, Climatic Change, 81, 119-159, doi:10.1007/s10584-006-9172-9, 2007.

Vehkamäki, H., Kulmala, M., Napari, I., Lehtinen, K. E. J., Timmreck, C., Noppel, M., and Laaksonen, A.: An improved parameterization for sulphuric acid-water nucleation rates for tropospheric and stratospheric conditions, J. Geophys. Res., 107, 4622, doi:10.1029/2002JD002184, 2002.

Vignati, E., Wilson, J., and Stier, P.: M7: an efficient size resolved aerosol microphysics module for large-scale aerosol transport models, J. Geophys. Res., 109, D22202, doi:10.1029/2003JD004485, 2004.

Wang, M. and Penner, J. E.: Aerosol indirect forcing in a global model with particle nucleation, Atmos. Chem. Phys., 9, 239-260, doi:10.5194/acp-9-239-2009, 2009.

Wise, M., Calvin, K., Thomson, A., Clarke, L., Bond-Lamberty, B., Sands, R., Smith, S. J., Janetos, A., and Edmonds, J.: Implications of Limiting CO2 Concentrations for Land Use and Energy, Science, 324, 1183-1186, 2009.

Yu, F. and Luo, G.: Simulation of particle size distribution with a global aerosol model: contribution of nucleation to aerosol and CCN number concentrations, Atmos. Chem. Phys., 9, 76917710, doi:10.5194/acp-9-7691-2009, 2009.

Yu, F., Luo, G., Bates, T. S., Andersson, B., Clarke, A., Kapustin, V., Yantosca, R. M., Wang, Y., and Wu, S.: Spatial distributions of particle number concentrations in the global troposphere: Simulations, observations, and implications for nucleation mechanism, J. Geophys. Res., 115, D17205, doi:10.1029/2009JD013473, 2010. 